\section{Psykisk helse og arbeid}

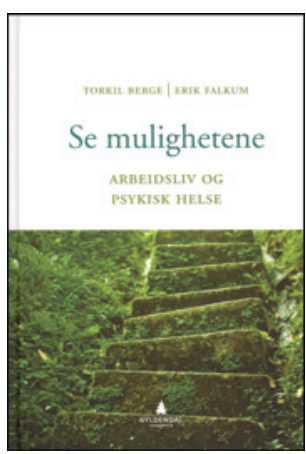

Torkil Berge, Erik Falkum

Se mulighetene

Arbeidsliv og psykisk helse. 331 s, ill. Oslo:

Gyldendal Akademisk, 2013. Pris NOK 469

ISBN 978-82-05-42845-4

Forfatterne er to erfarne klinkere og forskere som henvender seg til ansatte i helsevesenet, spesielt allmennleger, ansatte i NAV, ansatte som arbeider med helse, miljø og sikkerhet (HMS), og ledere og tillitsvalgte/verneombud i arbeidslivet.

Boken kan leses uten helseprofesjonell bakgrunn da språket er enkelt og forståelig. Gjenkjennelige pasienthistorier gjør teksten lettlest. De 22 kapitlene har undertitler som gjør stoffet lett tilgjengelig. Boken kan derfor brukes som en oppslagsbok etter at leseren er kjent med stoffet.

I første del redegjør forfatterne for forståelsesmodeller for samspill mellom psykisk sykdom og arbeidsliv. Stress- sårbarhetsmodellen er en modell for individuell sårbarhet og krav som møter den enkelte i arbeidslivet. Selvbestemmelsesteorien viser hvordan det etableres motivasjon i en endringsprosess. Arbeidets betydning for identitet og mental helse belyses gjennom anerkjennelsespsykologi. Dette er kapitler som kan brukes også for mennesker med andre diagnoser enn psykiske.

Del 2-5 omhandler spesifikke lidelser og behandlingen av disse med spesielt søkelys på jobbmestring. Diagnosene som oftest medfører sykmelding og uførhet, er depresjon, sosial angst og psykoselidelser. Behandlingen som omtales, er basert på kognitiv terapi, men modellene som presenteres for jobbmestring, kan kombineres med andre psykoterapeutiske tilnærminger. Dette er altså i utgangspunktet ikke en lærebok i kognitiv terapi. Psykoselidelser med individuell behandling og integrering i arbeidslivet vies også mye oppmerksomhet.

Hovedbudskapet er å integrere psykisk helsehjelp med tiltak på arbeidsplassen. Begge deler bør skje så tidlig som mulig i et sykmeldingsforløp. Forfatterne diskuterer sykmeldingsarbeid, jobbfokus i terapien, lavterskeltilbud og veiledet selvhjelp, etter modell fra storsatsing i England.

I den siste delen retter de søkelyset mot tiltak og holdninger i arbeidslivet, noe som vil være interessant for ansatte og ledere som arbeider med helse, miljø og sikkerhet (HMS). Utfordringer på arbeidsplassen - som omgangstone, utstøting og trakassering omtales. Samtidig viser forfatterne til arbeidsplassens mange viktige funksjoner: engasjement, arbeidsglød, meningsfull tid og sosialt liv.

Norge har i dag 700000 personer i yrkesaktiv alder som står helt eller delvis utenfor arbeidslivet. I den offentlige debatten fokuserer man på den økonomiske utfordringen ved dette. I Se mulighetene konsentrerer man seg om situasjonen til enkeltpersonene som står utenfor arbeidslivet. Hovedbudskapet er at vi må slutte å tenke behandling først og deretter integrering på arbeidsplassen. Disse prosessene må gå parallelt, og man behøver holdningsendringer $i$ helsevesenet og i NAV. Fastleger som sykmeldere vil ha stor nytte av denne boken. Den forenkler ikke, men viser til forskning og erfaringsbasert praksis. Anvisningene og rådene til behandlere og hjelpere er konkrete, og tonen er optimistisk: Det nytter!

\section{Nyttig mestringsbok ved stemningslidelser}

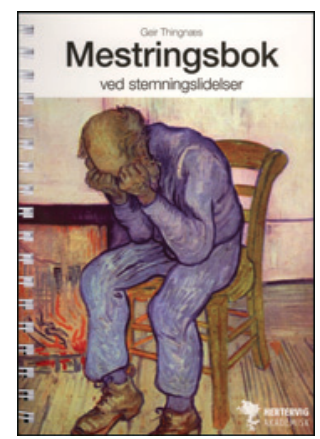

Geir Thingnæs

Mestringsbok ved stemningslidelser

2. utg. 271 s, ill. Stavanger: Hertervig

Akademisk, 2012. Pris NOK 270

ISBN 978-82-8217-206-6

Ifølge forfatteren er dette en mestringsbok for mennesker med stemningslidelse, der pasient og behandler samarbeider om å gå gjennom teksten og arbeide med de tallrike oppgavene. Meningen er, formoder jeg, at pasient og behandler fritt kan velge hvilke temaer de vil gjennomgå.

Det er et imponerende stykke arbeid som er gjort. Den delikate formen med spiralrygg, pent omslag og papirkvalitet gjør den egnet som arbeidsbok. Boken er delt inn i fire deler hvor man tar for seg generelle aspekter, kartlegging, behandling og avslutning. Hvert kapittel avsluttes med arbeidsoppgaver. Det er knapt et relevant tema som ikke er omtalt. At det ikke er et eget kapittel hvor man tar for seg forebygging av nye episoder, må være en forglemmelse. Et forebyggende perspektiv bør gjennomsyre enhver terapeutisk tilnærming, noe som burde tydeliggjøres. Kanskje burde man også fokusert mer eksplisitt på livsstil, selv om flere av kapitlene er livsstilsrelaterte.

Et par generelle forhold begrenser nytten av denne boken: Det er relativt liten skrift, og på tross av de mange oppgavene får den et kompakt preg som nok kan vanskeliggjøre tilegnelsen for noen. I perioder får boken et fagbokpreg som gjør at man kan undres på hvem den er skrevet for.

Noen konkrete innvendinger: I kapitlet Hva er depresjon? angis mulige depresjonssymptomer noe usystematisk uten at man klargjør hvilke som er hovedsymptomer og nødvendige for diagnosen. Senket stemningsleie, interesse- og gledeløshet og energitap burde vært fremhevet. Videre burde det vært gjort tydeligere at visse symptomer kun kan sannsynliggjøre om en depresjon hører hjemme $i$ et bipolart spekter og ikke at den er det, slik teksten gir inntrykk av. At maniske symptomer kan inngå i en depressiv episode og vice versa (blandet fase) er hoppet bukk over - selv om det er ganske vanlig forekommende og representerer spesielle behandlingsutfordringer. Bipolart spektrum er ikke omtalt. I ordlisten bak er det plutselig angitt «Bipolar 3» uten at jeg kan finne noe om det i teksten. Det er foretatt en bevisst avgrensing i forhold til angst. Det er greit nok, men ikke helt tilfredsstillende da mange pasienter sliter med begge deler. Kapitlet om antipsykotika er lite oppdatert. Begrepene årsak/ faktor/disposisjon/sårbarhet er brukt upresist og egnet til å forvirre.

Likevel, boken vil kunne ha nytteverdi i møte mellom pasient og behandler.

Terje Øiesvold

Spesialist i Bodø 